\title{
Head and face injuries among cyclists admitted to the Craniomaxillofacial and Oncological Department at the Medical University of Lodz
}

\section{Charakterystyka najczęstszych urazów głowy i twarzy wśród rowerzystów przyjętych na Oddział Chirurgii Czaszkowo-Szczękowo-Twarzowej i Onkologicznej Szpitala Klinicznego Uniwersytetu Medycznego w Łodzi}

\author{
Aleksandra Puch ${ }^{1, B, D, F}$, Aneta Neskoromna-Jędrzejczak ${ }^{1, C, F}$, Artur Chomik², ${ }^{2, F}$, Katarzyna Bogusiak2,A,B,F \\ 1 Department of Craniomaxillofacial and Oncological Surgery, Medical University of Lodz, Łodź, Poland \\ 2 Department of Craniomaxillofacial and Oncological Surgery, Barlicki University Hospital, Łódź, Poland \\ A - research concept and design; $\mathrm{B}$ - collection and/or assembly of data; $\mathrm{C}$ - data analysis and interpretation; \\ $D$ - writing the article; $E$ - critical revision of the article; $F$ - final approval of article
}

\section{Address for correspondence}

Aleksandra Puch

E-mail: puch.aleksandra@wp.pl

Funding sources

none declared

Conflict of interest

none declared

Received on March 04, 2017

Revised on May 30, 2017

Accepted on June 16, 2017

DOI

10.17219/dmp/74923

Copyright

○ 2017 by Wroclaw Medical University

and Polish Dental Society

This is an article distributed under the terms of the

Creative Commons Attribution Non-Commercial License

(http://creativecommons.org/licenses/by-nc-nd/4.0/)

\begin{abstract}
Background. Cycling is a very popular type of activity in our times. People of all ages use bikes for many purposes like sport, entertainment or as means of transport. Unfortunately, this activity exposes cyclists to more frequent injuries of the face and head region.

Objectives. The aim of this study was to characterize bike-related injuries with special consideration to the injuries to the facial region. Secondly, we investigated the impact of wearing helmets on head and facial region traumas.
\end{abstract}

Material and methods. In our retrospective research, we analyzed 41 patients (28 men and 13 women) aged between $33.2 \pm 13.3$. The data included in our study concerned the age, sex, duration of hospitalization, type of bike, types of injuries and fractures, cause of injury, circumstances, place and type of accident, wearing helmet during injury and the occurrence of brain concussion.

Results. Men were the most prevalent in the analyzed group of patients (68.3\%). Dental traumas were the most commonly observed type of injuries - they were diagnosed in 21 out of 41 patients (51.2\%). Soft issue injuries were observed in 19 out of 41 cases (46.3\%). Fractures of the facial skeleton were the rarest - they were noted in 13 people, in 4 of them mandibular fractures were observed. A statistically significant dependency was observed that people with helmets were more likely to suffer from coexisting traumas in comparison to those without them. The cause of brain concussion was statistically correlated with the type of accident.

Conclusions. Males more often experienced accidents than females. Falling from a bike caused most accidents. The most frequent among injuries were dental traumas and among fractures - mandibular fractures. Cyclists wearing helmets had more frequently coexisting traumas. Brain concussions mostly resulted from traffic crashes.

Key words: injuries, head trauma, cyclists, helmets, traumatic brain injury

Słowa kluczowe: urazy, urazy głowy, rowerzyści, kaski, wstrząs mózgu 
Cycling is a very popular type of activity in our times. People of all ages use bikes for many purposes like sport, entertainment or as a means of transport ${ }^{1}$. Despite many advantages, cycling is also associated with a higher risk of various accidents and many serious traumas, sometimes even fatal ones. ${ }^{2-4}$ According to Polish statistics collected in 2011, the percentage of cyclists seriously injured reached $9.2 \%$ and fatally injured reached $7.5 \% .^{5}$ Poland is one of the countries were the risk for "unprotected" road participants (which include pedestrians, cyclists, motorcyclists) is very high. ${ }^{6}$ In road accidents in 2010, pedestrians and cyclists constitute 30\% of all injured and 39\% of fatalities. However, in 2015 these numbers were even higher, respectively $32 \%$ and $42 \%$, thereby becoming one of the highest results among other countries of the European Union. ${ }^{7}$

There is official data on bike-related accidents in Poland gathered by government institutions based on data collected from 38 units, including the Ministry of Infrastructure, management of roads and units of traffic managers. The database obtained by the Supreme Chamber of Control showed that the number of accidents involving cyclists in different periods - 2010 compared with 2015 - increased by $18.3 \%$ and the number of injured cyclists increased to about $16.9 \%{ }^{6}$ Also, in the Lódź region an increased amount of incidents caused by bicycles can be observed - in 2013 it was 186 and in 2015 it was $207 .{ }^{8}$ However, data coming from so many sources seems to be incomplete, as it does not include injury characteristics.

Cyclists are at a higher risk of dangerous traumas, but they are especially exposed to major head and face injuries. Helmets are one of the suggested precautions aiming to provide cyclists adequate protection.

Some articles confirmed that helmets protect cyclists from complications associated with traumatic brain injuries and are effective in reducing the risk of head injury. ${ }^{9,10}$ But on the other hand, there is no association between helmet use and the risk of facial injuries. Also, they do not protect the lower facial region. ${ }^{11,12}$

Not every type of bicycle helmet protects in the same way. Sometimes cyclists with helmets increase their speed and have decreased risk perception and because of that the safety effect can be counterproductive. ${ }^{1}$

The aim of this study was to characterize bike-related injuries with special consideration to the injuries to the facial region. Secondly, we investigated the impact of wearing helmets on head and facial region traumas.

\section{Material and methods}

Our research contained 41 patients with cyclist-related injuries admitted to the Maxillofacial and Oncological Department at the Medical University of Lodz between the years 2013 and 2016. The mean age of the patients was $33.2 \pm 13.3$. Twenty-eight $(68.3 \%)$ of them were male with the average age of 34 years and only 13 (31.7\%) were female with the average age of 31 years. The data included in our study concerned the age, sex, duration of hospitalization, type of bike, types of injuries and fractures, circumstances, place and type of accident. Additionally, the most commonly types of injuries among helmeted and non-helmeted cyclists were characterized with particular attention paid to patients with brain concussion and facial region traumas.

\section{Statistical analysis}

At first, the rate structure was calculated. For comparison, the frequency a $\chi^{2}$ test with the Yates amendment was used to analyze the epidemiological data. An univariate regression analysis was performed, and a statistically significant $\mathrm{p}$ value $<0.05$ was assigned.

\section{Results}

In the analyzed group of patients, men prevailed (68.3\%). Fifty-six point one percent of patients were over 30 years old. The duration of hospitalization equaled from 1 to 10 days, in an average of $2.8 \pm 2.6$ days. Slightly more than half of the patients were hospitalized only for 1 day. The mean length of hospitalization in the case of male patients was 2.4 days and in the case of female patients was 3.5 days.

Dental traumas were the most commonly observed type of injuries - they were observed in $51.2 \%$ of cyclists. They consisted of tooth luxations that were diagnosed in 16 out of 41 patients and tooth fractures - in 5 out of 41 patients. The second most common type of traumas were soft issue injuries which were observed in $46.3 \%$ of patients. Fractures of the facial skeleton were the rarest - they were noted in 11 people, in 4 of them mandibular fractures were observed, in 4 zygomaticomaxillary complex fracture, in 2 nasal bone fracture and only in 1 case orbital floor fracture was present.

Concomitant traumas occurred only in $31.7 \%$ of patients. Ten out of 13 cases had soft tissue injuries of the upper extremities and in 3 subjects fractures of upper extremities were noted. Among men, the most frequent injuries were dental traumas and then soft tissue injuries, whereas in the case of women, the tendency was reverse. Twenty-two percent of patients confirmed that they were wearing a helmet at the time of the accident. Among them, $21.4 \%$ were male and $23 \%$ were female. In all cases, the most frequent cause of injuries was a fall from the bicycle $(73.2 \%)$. Only $26.8 \%$ had a road accident. Detailed data is shown in Table 1.

During the accident $46.1 \%$ of women confirmed using a trekking bike. Fifty percent of men declared using a mountain bike at the time of the accident. The accurate data is presented in Table 2 . 
Table 1. Characteristics of accidents

\begin{tabular}{|c|c|c|c|c|c|}
\hline \multirow{3}{*}{ Type of injuries* } & \multicolumn{4}{|c|}{ Sex } & \multirow{3}{*}{ p-value } \\
\hline & \multicolumn{2}{|c|}{$\begin{array}{c}\text { men } \\
(n=28)\end{array}$} & \multicolumn{2}{|c|}{$\begin{array}{l}\text { women } \\
(n=13)\end{array}$} & \\
\hline & $n$ & $\%$ & $n$ & $\%$ & \\
\hline Tooth luxatio & 12 & 43 & 4 & 31 & 0.693 \\
\hline Tooth fracture & 3 & 11 & 2 & 15 & 0.930 \\
\hline Soft tissue injuries & 12 & 43 & 7 & 54 & 0.511 \\
\hline $\begin{array}{l}\text { Fractures of facial skeleton } \\
\text { (mandible) }\end{array}$ & 2 & 7 & 2 & 15 & 0.793 \\
\hline $\begin{array}{l}\text { Fractures of facial skeleton } \\
\text { (zygomaticomaxillary } \\
\text { complex fracture) }\end{array}$ & 2 & 7 & 2 & 15 & 0.793 \\
\hline Fractures of nasal bones & 1 & 4 & 1 & 8 & 0.834 \\
\hline Fractures of facial skeleton & 1 & 4 & 1 & 8 & 0.834 \\
\hline Fractures of orbital floor & 1 & 4 & - & - & 0.691 \\
\hline Cause of injuries & & & & & 0.993 \\
\hline Fall from a bike & 20 & 71 & 10 & 77 & \\
\hline Road accident & 8 & 29 & 3 & 23 & \\
\hline Coexisting injuries & & & & & 0.455 \\
\hline Soft tissue injuries of extermities & 6 & 21 & 4 & 31 & \\
\hline Fracture of radial bone & 1 & 4 & 2 & 16 & \\
\hline Cases without coexisting injuries & 21 & 75 & 7 & 53 & \\
\hline Brain concussion & & & & & 0.691 \\
\hline No & 19 & 68 & 8 & 62 & \\
\hline Yes & 9 & 32 & 5 & 38 & \\
\hline Injuries of helmeted cyclists & & & & & 0.774 \\
\hline No & 22 & 79 & 10 & 77 & \\
\hline Yes & 6 & 21 & 3 & 23 & \\
\hline
\end{tabular}

* Number of injuries is bigger than the number of patients because some of them had more than one injury.

Cyclists using trekking or city bikes experienced less dental trauma than others bike users $(\mathrm{p}<0.05)$. This is in contrast to cyclists using mountain bikes, who more often suffered because of dental trauma $(p<0.05)$. And the most common place where this type of injury occurred was a bicycle path in the city $(\mathrm{p}<0.05)$. Traumas like soft

Table 2. Characteristics of injuries

\begin{tabular}{|c|c|c|c|c|c|c|c|c|}
\hline \multirow{2}{*}{ Categories } & \multicolumn{2}{|c|}{ City } & \multicolumn{2}{|c|}{ Treckking } & \multicolumn{2}{|c|}{ Mountain } & \multicolumn{2}{|c|}{ Road } \\
\hline & $n$ & $\%$ & $n$ & $\%$ & $\mathrm{n}$ & $\%$ & $\mathrm{n}$ & $\%$ \\
\hline \multicolumn{9}{|l|}{ Sex } \\
\hline Woman & 4 & 30.8 & 6 & 46.1 & 3 & 23.1 & 0 & 0 \\
\hline Man & 7 & 25 & 3 & 10.7 & 14 & 50 & 4 & 14.3 \\
\hline \multicolumn{9}{|l|}{ Type of Injury } \\
\hline Facial fracture & & 4 & & 3 & & 4 & & 0 \\
\hline Dental trauma & & 4 & & 5 & & 10 & & 2 \\
\hline Soft tissue injuries & & 4 & & 5 & & 8 & & 2 \\
\hline \multicolumn{9}{|l|}{ Cause of Injury } \\
\hline Fall & & 6 & & 7 & & 13 & & 4 \\
\hline Collision & & 3 & & 4 & & 4 & & 0 \\
\hline
\end{tabular}

Table 3. Comparison of injuries

\begin{tabular}{|c|c|c|c|}
\hline \multicolumn{4}{|l|}{ Trekking bike } \\
\hline Fracture & yes & other & \\
\hline Yes & 3 & 8 & \\
\hline No & 8 & 22 & $p<0.05$ \\
\hline \multicolumn{4}{|l|}{ Trekking bike } \\
\hline Dental trauma & yes & other & \\
\hline Yes & 5 & 16 & \\
\hline No & 6 & 14 & $p<0.05$ \\
\hline \multicolumn{4}{|l|}{ City bike } \\
\hline Dental trauma & yes & other & \\
\hline Yes & 4 & 17 & \\
\hline No & 5 & 15 & $p<0.05$ \\
\hline \multicolumn{4}{|l|}{ Mountain bike } \\
\hline Dental trauma & yes & other & \\
\hline Yes & 10 & 11 & \\
\hline No & 7 & 13 & $p<0.05$ \\
\hline \multicolumn{4}{|l|}{$\begin{array}{l}\text { Bicycle path } \\
\text { inside the city }\end{array}$} \\
\hline Dental trauma & yes & other & \\
\hline Yes & 9 & 12 & \\
\hline No & 3 & 17 & $p<0.05$ \\
\hline \multicolumn{4}{|l|}{$\begin{array}{l}\text { Bicycle path } \\
\text { inside the city }\end{array}$} \\
\hline Soft tissue injuries & yes & other & \\
\hline Yes & 2 & 17 & \\
\hline No & 0 & 22 & $p<0.05$ \\
\hline \multicolumn{4}{|l|}{ Roadside } \\
\hline Soft tissue injuries & yes & other & \\
\hline Yes & 1 & 18 & \\
\hline No & 0 & 22 & $p<0.05$ \\
\hline
\end{tabular}

tissue injuries most often occurred as a result of accidents on bicycle paths outside the city and, contrary to that, the most infrequent place of this injury was the roadside $(\mathrm{p}<0.05)$ (Table 3).

Helmeted cyclists more often experienced injuries in collisions, while people cycling without helmets mostly experienced trauma because of the fall. This dependence occurred to be statistically significant $(\mathrm{p}<0.05)$.

Also, statistically significant was the observation that patients with helmets had a lower rate of coexisting traumas $(\mathrm{p}<0.01)$. Thirty-four percent of cyclists suffered a brain concussion. This trauma more often affected people who were not wearing a helmet at the time of the accident (37.5\%), but this dependence was not statistically significant. This data is shown in Table 4.

When the cause of trauma was the road accident, people more frequently had coexisting injuries and facial fractures than in cases when people fell from the bicycle. Also, $72.7 \%$ of them had a brain concussion, which proved to be statistically significant $(\mathrm{p}<0.01)$ (Table 5 ). 
Table 4. Characteristics of accidents

\begin{tabular}{|c|c|c|c|c|c|}
\hline \multirow{3}{*}{ Type of injuries* } & \multicolumn{4}{|c|}{$\begin{array}{c}\text { Did cyclists wear a helmet } \\
\text { during accident? }\end{array}$} & \multirow{3}{*}{$p$-value } \\
\hline & \multicolumn{2}{|c|}{ no $(n=32)$} & \multicolumn{2}{|c|}{ yes $(n=9)$} & \\
\hline & $\mathrm{n}$ & $\%$ & $\mathrm{n}$ & $\%$ & \\
\hline Tooth luxatio & 12 & 38 & 4 & 44 & 0.993 \\
\hline Tooth fracture & 5 & 16 & - & - & 0.357 \\
\hline Soft tissue injuries & 15 & 47 & 4 & 44 & 0.641 \\
\hline $\begin{array}{l}\text { Fractures of facial skeleton } \\
\text { (mandible) }\end{array}$ & 2 & 7 & 2 & 22 & 0.630 \\
\hline $\begin{array}{l}\text { Fractures of facial skeleton } \\
\text { (zygomaticomaxillary } \\
\text { complex fracture) }\end{array}$ & 2 & 7 & 2 & 22 & 0.630 \\
\hline Fractures of nasal bones & 2 & 4 & - & - & 0.941 \\
\hline Fractures of facial skeleton & 2 & 4 & - & - & 0.941 \\
\hline Fractures of orbital floor & 1 & 4 & - & - & 0.606 \\
\hline Cause of injuries & & & & & 0.0277 \\
\hline Fall from a bike & 26 & 81 & 4 & 44 & \\
\hline Road accident & 6 & 19 & 5 & 56 & \\
\hline Coexisting injuries & & & & & 0.0087 \\
\hline Soft tissue injuries of extermities & 8 & 25 & 2 & 22 & \\
\hline Fracture of radial bone & - & - & 3 & 34 & \\
\hline Cases without coexisting injuries & 24 & 75 & 4 & 44 & \\
\hline Brain concussion & & & & & 0.648 \\
\hline No & 20 & 63 & 7 & 78 & \\
\hline Yes & 12 & 37 & 2 & 22 & \\
\hline
\end{tabular}

* Number of injuries is bigger than the number of patients because some of them had more than one injury.

\section{Discussion}

In the a cross-sectional study that analyzed 2008-2011 years, the major group of victims of bike-related accidents in Poland were people on average aged between 20 and 40 years and $70.2 \%$ of them were male. ${ }^{5}$ Our study also confirmed that fact $-68.3 \%$ of our patients were male in the mean age of 33.9 years. Many other researches on bicycle crashes have shown that adult males pose the major risk group. ${ }^{1,2,4,14,15}$ The higher level of risk-taking behaviors in this group was probably caused by the young age of cyclists..$^{13}$ Accidents most often occurred when cycling for recreation or fitness purposes, which also increased the number of accidents among men as the main group of bicycles users. ${ }^{1,14,16}$ Different concepts, possibilities and reasons for accidents occurring among participants of this sport were extensively discussed. In the case of young people, trauma can be caused by inexperience and limited knowledge of traffic rules. On the other hand, among older people it can depend on their poor vision or longer reaction time. ${ }^{17}$

The data of cyclists collected for study purposes consists of age, sex, helmet usage, type of injury, concussion and the type of accident. We did not collect data on the weight and height of patients, because they were not reg-
Table 5. Correlation between the cause of the injury and observed injuries

\begin{tabular}{|c|c|c|c|c|c|}
\hline \multirow{3}{*}{ Type of injuries* } & \multicolumn{4}{|c|}{ Cause of injuries } & \multirow{3}{*}{$p$-value } \\
\hline & \multicolumn{2}{|c|}{$\begin{array}{l}\text { fall from } \\
\text { a bike }\end{array}$} & \multicolumn{2}{|c|}{$\begin{array}{c}\text { road } \\
\text { accident }\end{array}$} & \\
\hline & $n$ & $\%$ & $n$ & $\%$ & \\
\hline Tooth luxatio & 12 & 40 & 4 & 36 & 0.881 \\
\hline Tooth fracture & 5 & 17 & - & - & 0.365 \\
\hline Soft tissue injuries & 16 & 53 & 3 & 27 & 0.259 \\
\hline $\begin{array}{l}\text { Fractures of facial skeleton } \\
\text { (mandible) }\end{array}$ & 1 & 3 & 3 & 27 & 0.090 \\
\hline $\begin{array}{l}\text { Fractures of facial skeleton } \\
\text { (zygomaticomaxillary } \\
\text { complex fracture) }\end{array}$ & 2 & 7 & 2 & 18 & 0.612 \\
\hline Fractures of nasal bones & - & - & 2 & 18 & 0.115 \\
\hline Fractures of facial skeleton & - & - & 2 & 18 & 0.115 \\
\hline Fractures of orbital floor & - & - & 1 & 9 & 0.597 \\
\hline Coexisting injuries & & & & & 0.448 \\
\hline Soft tissue injuries of extermities & 8 & 27 & 2 & 18 & \\
\hline Fracture of radial bone & 1 & 1 & 2 & 18 & \\
\hline Cases without coexisting injuries & 21 & 70 & 7 & 64 & \\
\hline Brain concussion & & & & & 0.0054 \\
\hline No & 24 & 80 & 3 & 27 & \\
\hline Yes & 6 & 20 & 8 & 73 & \\
\hline
\end{tabular}

* Number of injuries is bigger than the number of patients because some of them had more than one injury.

istered after every accident in the medical documentation. As with most studies based on clinical or survey data, the weight and height are rarely recorded. ${ }^{15,16}$ It seems that they are more important in the mechanism of the accident itself and in the evaluation of the intensity of the suffered injury only at the moment of direct reconstruction of the event..$^{18}$ The correlation between the weight, height and severity of head injuries was hard to observe in other studies, because none of the authors, despite collecting this data, included this in their statistics. ${ }^{15,16}$

In our research of different types of injuries, dental traumas dominated, followed by soft tissue injuries and fractures of the facial skeleton (mandible, zygomatic complex, nasal bone and orbit floor fractures). We detected that a fall from a bike was a major cause of injury.

In most studies, head injuries were frequently mentioned as the primary trauma. ${ }^{1,13,15}$ Facial skeleton fractures (mandibular, condylar fractures, dentoalveolar traumas) were the second most commonly reported types of injuries. ${ }^{19}$ Stier et al. observed that the most commonly occurring fractures were those that concerned the nasal bone, orbital bone, zygomatic bone, maxilla and mandible. ${ }^{20}$ Some authors also confirmed that falling is one of the major causes of injury, especially among older people., ${ }^{1,21}$ However, most researchers regarded collisions as the main causes of accidents. ${ }^{22-24}$ It was proved that head injuries were the main cause of hospitalization and were responsible for deaths in $69-93 \%$ of fatal bicycle accidents. ${ }^{4,13}$ Soft 
tissue injuries most frequently were caused by accidents on bicycle paths outside the city and least often appeared in accidents on the roadside. De Geus et al. confirmed that major and fatal accidents more frequently take place in less urbanized areas in contrast to urban areas. ${ }^{16}$

Literature data also analyzed the occurrence of a particular injury according to the type of bicycle and the place of accident. In our research we observed that men more often than women suffered accidents and they were more frequently using a mountain bike. This may possibly be due to the fact that females were less likely to demonstrate risky behavior when cycling. ${ }^{25}$ However, older people (over 50 years old) were more likely to prefer other bikes, such as electrically assisted bicycles, city bikes and only $2 \%$ chose mountain bikes. ${ }^{26}$

Twenty-two percent of our study population was wearing a helmet during their accident. Most of them were men. People cycling without any safety measures were mostly injured due to a fall after losing control of their vehicles. Helmeted cyclists were most likely to be injured due to a street collision. It was found statistically significant that people wearing helmets were more likely to suffer from coexisting traumas (55.5\%) then those without them (26.7\%). Many other authors obtained similar results. However, the fact that the group wearing helmets was more likely to suffer from coexisting traumas can be explained by their feeling of safety and general tendency to engage in more risky behaviors. It was affirmed that other road users, i.e. car drivers would in general pass closer to a cyclist wearing a helmet, which could be an example of risk compensation. A car driver would most likely assume that a cyclist wearing a helmet has more road experience and is less likely to act erratically. ${ }^{1,3,5}$

In our research $37.5 \%$ of cyclists without helmets suffered from concussions as a result of their accidents, whereas only $22.2 \%$ of the population with helmets received the same injuries. The cause of concussions was statistically correlated with the type of accident. Only in $20 \%$ of cases concussions followed a fall from bike, while even $72.7 \%$ of concussions were a results of traffic crashes. The cause of injury was also an important factor in reference to the type of trauma. Collisions were most likely to cause fractures in the craniofacial region, while a fall was predominantly related with dental trauma.

The efficacy of helmets against major head trauma and facial injuries is a debatable question. There is no conclusive research about this problem. However, some authors show that there is a lack of scientific evidence that various types of helmet protect in the same way against brain injury, ${ }^{27}$ which also makes it more difficult to evaluate their effectiveness. Rivara et al. stated that cycling with a helmet can significantly reduce the risk of fatality, but was not associated with the severity of the injury. ${ }^{2}$ This research also confirmed our statement about the fact that a collision with a vehicle increased the risk of severe injuries. ${ }^{2}$
Dagher et al. noticed that cyclists without helmets had more severe traumatic brain injuries, however this obserwation was not statisticaly significent. On the other hand, they found that helmeted cyclist had a higher risk of polytrauma. ${ }^{9}$

Many studies still confirm the protective effects of helmets in the case of head and face injuries. ${ }^{28-30}$ Amoros et al. claimed that cyclists with helmets were more frequently involved in collisions with pedestrians or bicycles and had a higher appearance of coexisting injuries in regions other than the head and face, which is similar to our results. ${ }^{28}$

Considering the cyclists' speed, which is very important in regards to accidents, we are not able to present this factor in our study. In Poland, speedometers are not popular bicycle gadgets, especially because of economic reasons. In the literature it is also a rarely discussed problem. This factor can be most frequently found in sponsored researches. ${ }^{21,31,32}$ Recording such types of data is hard because of the difficult access to this information and the lack of accurate measurements of speed during the collision. Likewise, studies focusing on cyclist-car accidents for the most part include data about speed of motor vehicles - not cyclists. In relation to cyclists, it was stated that their average speed was $18.6 \mathrm{~km} / \mathrm{h}$, cyclists on mountain bikes reach $20.5 \mathrm{~km} / \mathrm{h}$, on road or racing bikes $(25.5 \mathrm{~km} / \mathrm{h})$ and slower on city bicycles $(17 \mathrm{~km} / \mathrm{h}) .{ }^{33}$ Kuehn's research emphasizes that the faster speed of cars, $51 \mathrm{~km} / \mathrm{h}$, causes more severe injuries. ${ }^{33}$ Also, in the case of cyclists' injuries, it was observed that increased speed was not correlated with the higher possibility of head injuries. On the other hand, lower speed of vehicles resulted in a minimal amount of fatal injuries among helmeted cyclists and decreased fatality in non-helmeted cyclists. ${ }^{34,35}$

\section{Conclusion}

Men are a higher risk group in regards to accident. The head and face area are the body regions most exposed to injuries. People experienced more severe traumas in the case of collisions and also more frequently had brain concussions. Cyclists with helmets had more coexisting injuries. Bike users with helmets probably felt more confident on the road and demonstrated more risky behaviors, which resulted in more dangerous accidents.

\section{References}

1. Eilert-Petersson E, Schelp L. An epidemiological study of bicyclerelated injuries. Accid Anal Prev. 1997;29:363-372.

2. Rivara FP, Thompson DC, Thompson RS. Epidemiology of bicycle injuries and risk factors for serious injury. Inj Prev. 2015;21:47-51.

3. Gaudet LTR, Romanow N, Nettel-Aguirre A, Voaklander DE, Hagel BH, Rowe B. The epidemiology of fatal cyclist crashes over a 14-year period in Alberta, Canada. BMC Public Health, 2015;15:1142-1150.

4. Hefny AF, Eid HO, Grivna M, Abu-Zidan FM. Bicycle-related injuries requiring hospitalization in the United Arab Emirates. Injury, 2012;43:1547-1550 
5. Kopta T, Buczyński A, Hyła M, Lustofin B. Traffic incidents involving cyclists in 2008-2011. General Directorate for National Roads and Motorways. Warsaw, 2012. https://www.gddkia.gov.pl/userfiles/articles/i/ infrastruktura-rowerowa_3000/zdarzenia_rowerowe_2008_2011.pdf. Accessed March 4, 2017.

6. Emiljah T. Safety of pedestrians and cyclists on public roads. Supreme Chamber of Control. Warsaw 2016. https://www.nik.gov. pl/kontrole/wyniki-kontroli-nik/pobierz,kin p_15_034_201512221 434551450794895 01,typ,kk.pdf. Accessed March 4, 2017.

7. Bieńkowski M. Tasks carried out by the police and the town guard (municipality) to ensure the safety of pedestrians and cyclists. Supreme Chamber of Control. Warsaw 2016. https://www.nik.gov. pl/plik/id,12353,vp,14740.pdf. Accessed March 4, 2017.

8. Cmela P, et al. Statistical yearbook łódzkie voivodship 2016. Statistical office in Łódź. Warsaw, 2016. http://lodz.stat.gov.pl/download/ gfx/lodz/pl/defaultaktualnosci/752/6/18/1/201612_r_rocznik_ lodzkie_2016.pdf. Accessed date: 04.03.2017.

9. Dagher JH, Costa C, Lamoureux J, de Guise E, Feyz M. Comparative outcomes of traumatic brain injury from biking accidents with or without helmet use. Can J Neurol Sci. 2016;43:56-64.

10. Klein K, Thompson D, Scheidt P, Overpeck M, Gross LH. Factors associated with bicycle helmet use among young adolescents in a multinational sample. Inj Prev. 2005;11:288-293.

11. Hwang K, Jeon YM, Ko YS, Kim YS. Relationship between location of facial injury and the use of bicycle helmets: A systematic review. Arch Plast Surg. 2015;42:407-410.

12. Acton $\mathrm{CH}$, Nixon JW, Clark RC. Bicycle riding and oral/maxillofacial trauma in young children. Med J Aust. 1996;165:249-251.

13. Depreitere B, et al. Bicycle-related head injury: A study of 86 cases. Accid Anal Prev. 2004;36:561-567.

14. Lee $\mathrm{KH}$, Chou HJ. Facial fractures in road cyclists. Aust Dent J. 2008;53:246-249.

15. Beck $B$, et al. Bicycling crash characteristics: An in-depth crash investigation study. Accid Anal Prev. 2016;96:219-227.

16. de Geus B, et al. A prospective cohort study on minor accidents involving commuter cyclists in Belgium. Accid Anal Prev. 2012;45:683-693.

17. Martínez-Ruiz V, Jiménez-Mejías E, Luna-del-Castillo Jde D, García-Martín M, Jiménez-Moleón JJ, Lardelli-Claret P. Association of cyclists' age and sex with risk of involvement in a crash before and after adjustment for cycling exposure. Accid Anal Prev. 2014;62:259-267.

18. Nie J, Jikuang Y. A study of bicyclist kinematics and injuries based on reconstruction of passenger car-bicycle accident in China. Accid Anal Prev. 2014;71;50-59.

19. Uibel S, Müller D, Klingelhoefer DA, Gronberg D. Bicycle helmet use and non-use - recently published research. J Occup Med Toxicol. 2012;7:9-18.

20. Stier R, et al. Effectiveness of bicycle safety helmets in preventing facial injuries in road accidents. Arch Trauma Res. 2016;5:85-89.

21. Scheiman S, Moghaddas HS, Björnstig U, Bylund PO, Saveman BI. Bicycle injury events among older adults in Northern Sweden: A 10-year population based study. Accid Anal Prev. 2010;42:758-763.

22. Walker I. Drivers overtaking bicyclists: Objective data on the effects of riding position, helmet use, vehicle type and apparent gender. Accid Anal Prev. 2007;39:417-425.

23. Phillips RO, Fyhri A, Sagberg F. Risk compensation and bicycle helmets. Risk Anal. 2011,31:1187-1195.

24. Robinson DL. No clear evidence from countries that have enforced the wearing of helmets. BMJ, 2006;332:722-725.

25. Garrard J, Rose G, Lo SK. Promoting transportation cycling for women: The role of bicycle infrastructure. Prevent Med. 2008;46:55-59.

26. BoeleVos MJ, Van Duijvenvoorde K, Doumen MJ, Duivenvoorden CW, Louwerse WJ, Davidse RJ. Crashes involving cyclists aged 50 and over in the Netherlands: Anin-depth study. Accid Anal Prev. 2016;48:328-334.

27. Curnow WJ. Bicycle helmets: Lack of efficacy against brain injury. Accid Anal Prev. 2006;38:833-834.

28. Amoros E, Chiron M, Martin JL, Thélot B, Laumon B. Bicycle helmet wearing and the risk of head, face, and neck injury: A French case - control study based on a road trauma registry. Inj Prev. 2012;18:27-32.

29. Dinh MM, et al. Mechanisms, injuries and helmet use in cyclists presenting to an inner city emergency department. Emerg Med Australas. 2015;27:323-327.
30. Thompson DC, Thompson RS, Rivara FP, Wolf ME. A case-control study of the effectiveness of bicycle safety helmets in preventing facial injury. Am J Public Health. 1990;80:1471-1474.

31. Witte TH, Wilson AM. Accuracy of non-differential GPS for the determination of speed over ground. J Biomech. 2004;37:1891-1898.

32. Boele-Vosa MJ, Commandeura JJF, Twisk DAM. Effect of physical effort on mental workload of cyclists in real traffic in relation to age and use of pedelecs. Accid Anal Prev. 2016;48:256-262.

33. Kuehn M, Hummel T, Lang A. Cyclist-car accidents - their consequence for cyclists and typical accident scenarios. German Insurers Accident Research, Germany Paper Number 15-0243.

34. Twisk DAM, Platteela S, Lovegrove GR. An experiment on rider stability while mounting: Comparing middle-aged and elderly cyclists on pedelecs and conventional bicycles. Available online 24 January 2017. doi: 10.1016/j.aap.2017.01.004.

35. McNally DS, Rosenberg NM. MADYMO simulation of children in cycle accidents: A novel approach in risk assessment. Accid Anal Prev. 2013;59:469-478. 